\title{
Stress response of a boreo-alpine species of tardigrade, Borealibius zetlandicus (Eutardigrada, Hypsibiidae)
}

\author{
Lorena REBECCHI ${ }^{1)}$, Deborah BOSCHINI ${ }^{2,1)}$, Michele CESARI ${ }^{2)}$, Valeria LENCIONI $^{2)}$, Roberto BERTOLANI ${ }^{1)}$ and \\ Roberto GUIDETTI ${ }^{3)}$ \\ ${ }^{1)}$ Department of Animal Biology, University of Modena and Reggio Emilia, Via Campi 213/D, 41100, Modena, Italy \\ ${ }^{2}$ Department of Invertebrate Zoology and Hydrobiology, Museum of Natural Science of Trento, Trento, Italy \\ ${ }^{3)}$ Department of the Museum of Paleobiology and Botanical Garden, University of Modena and Reggio Emilia, Modena, Italy \\ * e-mail corresponding author: rebecchi.lorena@unimore.it
}

\begin{abstract}
Invertebrates living in extreme environments as well as those living under unpredictable habitat conditions must be able to survive severe environmental stresses bound to their habitats. Tardigrades represent a good animal model to analyze responses evolved by organisms to overcome extreme environmental stresses or to colonize extreme environments because they respond to desiccation or freezing in their habitats by entering cryptobiosis. The responses to environmental stresses have been evaluated almost exclusively in terrestrial tardigrades, while very little is known about the ability of limnic species to tolerate those stresses. This study evaluates the responses of the limnic boreo-alpine species Borealibius zetlandicus, under lab conditions, to stresses imposed by desiccation and temperature variation (freezing and heating). Our results indicate that active specimens are able to freeze, confirming the cryobiotic ability of this species. There is a negative correlation between survival and cooling rates. In contrast, no specimens of $\mathrm{B}$. zetlandicus are able to survive desiccation. With regard to thermal tolerance, the animals show a high ability to resist heat-shock $\left(L T_{50}=33.0 \pm 0.5^{\circ} \mathrm{C}\right)$ for a short time. This wide tolerance to different environmental parameters could be the reason for the wide distribution of the species. Due to the disjunct distribution of the species and to the potential presence of cryptic tardigrade species that could have different ecological and physiological responses, we decided to characterize the population studied from a molecular point of view by investigating its COI mtDNA sequences.
\end{abstract}

Key words: thermal stress, freezing, desiccation, limnic tardigrade, adaptive strategies, COI mtDNA

\section{INTRODUCTION}

Invertebrates living in extreme environments (polar regions, deserts, high elevations and high latitudes), as well as those living in unpredictable habitat conditions even at our temperate latitudes (e.g., mosses and lichens subject to desiccation or freezing, temporary ponds), must be able to survive strong environmental stresses characteristic of their habitats. These stresses can produce substantial modifications in the structure of biological communities, even with modifications of the functional integrity of the ecosystems (Irons et al. 1993). Organisms can respond to environmental stresses using regulative, acclimation, developmental and evolutionary responses (Willmer et al. 2000).

Tardigrades represent a good animal model to analyze responses evolved by organisms to overcome extreme environmental stresses or to colonize extreme environments. They are micrometazoans found worldwide and represent a component of meiofaunal communities of marine, limnic and above all terrestrial ecosystems (Nelson \& Marley 2000). More than one thousand species have been described to date (Guidetti \& Bertolani 2005; Degma \& Guidetti 2007), 75\% of which were found in limnic and/or in terrestrial environments where their abundance is very high in habitats with unpredict- able conditions. As a response to desiccation or freezing of their habitats, tardigrades reduce and suspend their metabolism, entering anhydrobiosis and cryobiosis, respectively (Bertolani et al. 2004). These two adaptive strategies represent different aspects of cryptobiosis (Keilin 1959), a widespread adaptive phenomenon of quiescence induced and maintained by environmental conditions adverse for an active life. Cryptobiosis promptly terminates when environmental conditions become again favorable for active life (Hand 1991). Tardigrades are able to enter cryptobiosis in any stage of their life cycle, from egg to adult, and desiccated or frozen tardigrades can stay alive even for several years (Rebecchi et al. 2007). Moreover, it is known that anhydrobiotic tardigrades can resist very high temperatures (up to $100^{\circ} \mathrm{C}$ ), in addition to several physical and chemical extremes (Rebecchi et al. 2007).

Responses to environmental stresses such as desiccation, freezing, and extremely high temperature, have been evaluated almost exclusively in terrestrial tardigrades (Sømme 1996; Bertolani et al. 2004; Li \& Wang 2005a, b; Rebecchi et al. 2007), while very little is known about the ability of limnic species to tolerate those stresses. Our present study reduces this gap by evaluating the responses of a limnic tardigrade species to stresses imposed by desiccation and temperature variation (freezing and heating). Information on the 


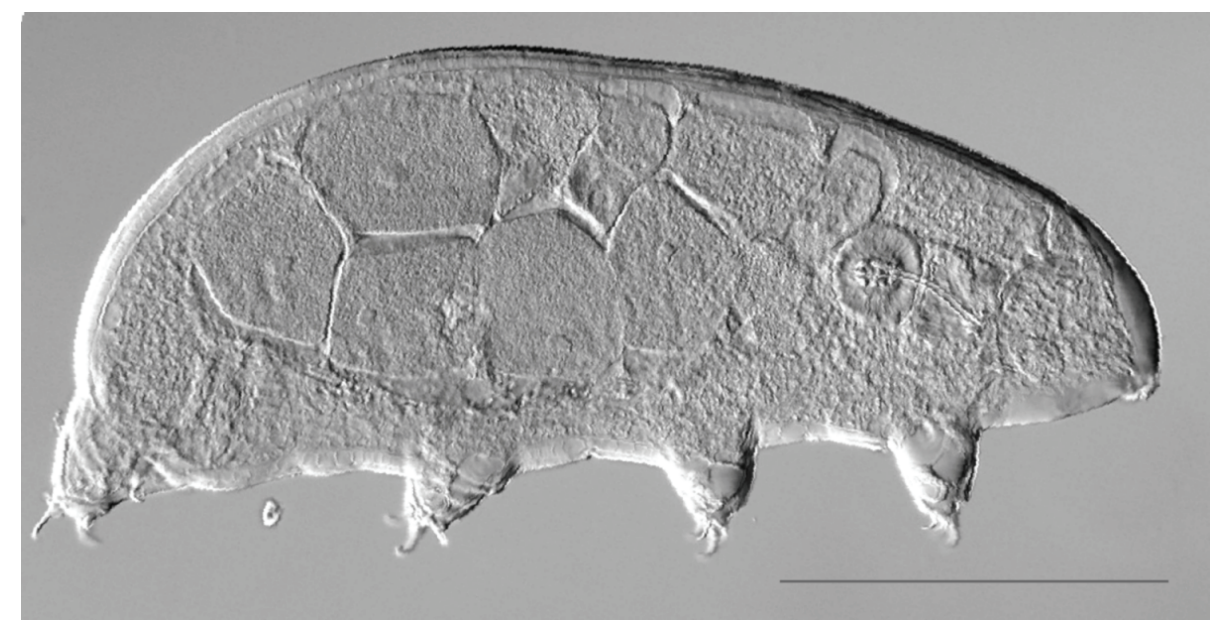

Fig. 1. Borealibius zetlandicus. The gonad of this specimen contains several oocytes (In vivo, Nomarski). Scale bar: $=200 \mu \mathrm{m}$.

evolution of regulative responses has great importance in a global scenario of environmental changes. As an experimental model the limnic eutardigrade Borealibius zetlandicus (Murray, 1907) was investigated. This species, with a boreo-alpine distribution (Pilato et al. 2006), is thus probably more sensitive to environmental changes than other tardigrade species. Finally, discovery of cryptic species in tardigrades, distinguishable only by molecular sequences (Faurby et al. 2008), has led to knowledge that different cryptic species can have different ecological niches and adaptive abilities despite their morphological similarity, thus emphasizing the need for molecular studies. Therefore we have analyzed COI mtDNA sequences of two populations of $B$. zetlandicus to describe it from a molecular point of view.

\section{METHODS}

\subsection{Species collection for experiment}

A submerged moss [Warnstorfia exannulata (Schimp.) Loeske] was collected in a spring located in Val de la Mare, Pian Venezia (Italian Alps, Stelvio National Park, Trentino, NE Italy, $46^{\circ} \mathrm{N} 26^{\prime}-010^{\circ} \mathrm{E} 40^{\prime}$, at $2270 \mathrm{~m}$ a.s.l.). The spring is characterized by transparent waters, rich in submerged mosses, with oxygen saturation of $64 \%$ and temperature ranging from $3.9{ }^{\circ} \mathrm{C}$ to $4.3{ }^{\circ} \mathrm{C}$. Moss was collected in November 2004, March 2005 and July 2005. Specimens of B. zetlandicus (Fig. 1) were extracted from mosses by washing the substrate on a sieve under running tap water and then individually picking up specimens under a stereo-microscope.

\subsection{Stress experiments}

To test the possibility that $B$. zetlandicus specimens can withstand desiccation or freezing, undergoing anhydrobiosis or cryobiosis, in addition to evaluating their thermal tolerance, we exposed tardigrades to stressful experimental conditions. After extraction, to standardize all stress experiments specimens of $B$. zetlandicus were starved for 24 hours in water at $10{ }^{\circ} \mathrm{C}$ before beginning each experiment.

\subsubsection{Experiment 1: Thermal stress}

Active adult specimens were used. Groups of tardigrades were placed in a covered glass cap $(4 \mathrm{~cm}$ in diameter) containing $4 \mathrm{~mL}$ of pre-heated mineral water and then exposed for $1 \mathrm{~h}$ to a specific stress temperature. The tested temperatures were $25^{\circ} \mathrm{C}, 26^{\circ} \mathrm{C}, 28^{\circ} \mathrm{C}$, $29^{\circ} \mathrm{C}, 30^{\circ} \mathrm{C}, 31{ }^{\circ} \mathrm{C}, 32{ }^{\circ} \mathrm{C}, 33{ }^{\circ} \mathrm{C}, 34^{\circ} \mathrm{C}, 36^{\circ} \mathrm{C}$ and 37 ${ }^{\circ} \mathrm{C}$. Five replicates were done for each temperature. Each replicate consisted of 5 tardigrades. As a control, five replicates were maintained at $10{ }^{\circ} \mathrm{C}$. After heat stress, the tardigrades were maintained at $10{ }^{\circ} \mathrm{C}$ and observed under a stereo-microscope to verify their viability. Coordinated movements of the body (locomotion performance) constituted the criterion to confirm animal viability. Locomotion performance was evaluated immediately after heat stress $\left(\mathrm{t}_{0}\right)$ and again $24 \mathrm{~h}$ $\left(\mathrm{t}_{24}\right)$ later. Survival was determined by the percentage of live animals at $t_{24}$. Data on survival were used to quantify thermal tolerance statistically by calculation of temperature that causes $50 \%$ mortality (lethal thermal temperature; $\mathrm{LT}_{50}$; Mora \& Maya 2006). The first temperature causing 100\% mortality (lethal thermal maximum, $\mathrm{LT}_{\max }$ ) was also determined. Statistical analyses (MannWhitney test, Pearson's correlation test and Probit analysis) were performed with SPSS 9.0 software.

\subsubsection{Experiment 2: Freezing stress}

Active adult specimens were used. Groups of tardigrades were frozen directly with $4 \mathrm{ml}$ of water in a covered cylindrical plastic container $(2 \mathrm{~cm}$ in diameter and $3 \mathrm{~cm}$ in height). Tested cooling rates were $-0.37{ }^{\circ} \mathrm{C}$ $\min ^{-1}$ (freezer $-9{ }^{\circ} \mathrm{C}$ ), $-0.69{ }^{\circ} \mathrm{C} \min ^{-1}$ (freezer $-20{ }^{\circ} \mathrm{C}$ ) and $-1.95^{\circ} \mathrm{C} \mathrm{min}^{-1}$ (freezer $-80^{\circ} \mathrm{C}$ ). Cooling rates were recorded by a thermocouple (Testo 735, pbi International). For all cooling rates, 4 replicates (with 10 animals each) were tested. Containers with animals were 
put directly into a freezer at one of the three cooling rates and the animals were kept frozen six days. Before the beginning of thawing, containers in the freezers at $-20{ }^{\circ} \mathrm{C}$ and $-80{ }^{\circ} \mathrm{C}$ were transferred to the freezer at -9 ${ }^{\circ} \mathrm{C}$ for $15 \mathrm{~h}$. All containers with animals were then transferred to $14{ }^{\circ} \mathrm{C}$ for thawing, i.e., to the complete melting of the ice. After thawing, all tardigrades were examined under a stereo-microscope to verify their viability (coordinated movements of the body). Locomotion performance was evaluated both after $2.5 \mathrm{~h}$ and $24 \mathrm{~h}$ after complete thawing of the ice in the containers. After $2.5 \mathrm{~h}$, mobile (live) animals were isolated, counted and fixed in Carnoy's fluid (methanol: acetic acid, 3:1). The immobile animals were kept in water at $10{ }^{\circ} \mathrm{C}$ for $24 \mathrm{~h}$. After that period these animals were re-examined under a stereo-microscope; those still immobile were considered dead. The percentage of the total number of animals found active both after $2.5\left(\mathrm{t}_{2.5}\right)$ and $24 \mathrm{~h}\left(\mathrm{t}_{24}\right)$ represented survival.

Statistical analyses were carried out with MannWhitney test and Pearson's correlation test using SPSS 9.0 software.

\subsubsection{Experiment 3: Desiccation stress}

Desiccation of animals was done according to a slightly modified protocol by Jönsson \& Rebecchi (2002). Active adult specimens were used. Each group of tardigrades was immersed in $120 \mu \mathrm{L}$ of water in a covered plastic tube (Mini Dyalizer tube $3550 \mathrm{MCW}$, Celbio; $10 \mathrm{~mm}$ in diameter and $20 \mathrm{~mm}$ in height) with a net in the bottom. Tests were run with 4 replicates (with 10 animals each). Animals were forced into anhydrobiosis by placing them in a climate controlled chamber at $16{ }^{\circ} \mathrm{C}$ and $85 \%$ of air relative humidity (RH). Animals were kept dry for 6 days. After the dry period, tardigrades were slowly re-hydrated by adding water drops within each plastic tube and observing them with a stereo-microscope to verify their viability (locomotion performance). Locomotion performance was evaluated both after $1 \mathrm{~h}$ and $24 \mathrm{~h}$ after re-hydration. During rehydration, tardigrades were maintained at $10{ }^{\circ} \mathrm{C}$.

\subsection{Molecular characterization}

Molecular analysis was performed on two specimens from the population of $B$. zetlandicus collected in Pian Venezia. Moreover, for comparison, two specimens were extracted from the sediment of nearby Nambino Lake (Italian Alps, Madonna di Campiglio, Trentino NE Italy; $\mathrm{N}^{\circ} 6^{\circ} 14^{\prime}-\mathrm{E} 010^{\circ} 36^{\prime} ; 1800 \mathrm{~m}$ a.s.l.), and subjected to molecular analysis. Before analysis, an accurate taxonomic inspection of all specimens was carried out, as tardigrades were observed in vivo in a drop of water under a coverglass, using differential interference contrast. In addition, for both populations, some animals were used as a voucher specimens were mounted in Faure-Berlese's fluid.
Total genomic DNA was extracted from single specimens using a salt and ethanol precipitation (Sunnucks \& Hales 1996). A fragment of the COI mitochondrial gene region was amplified using the Genespin kit with recombinant Taq DNA polymerase and using primers LCO1490 (5'-GGT CAA CAA ATC ATA AAG ATA TTG G-3') and HCO2198 (5'-TAA ACT TCA GGG TGA CCA AAA AAT CA-3') derived from Folmer et al. (1994). PCR reactions were carried out on a Hybaid PCR Sprint thermocycler executing a step-up procedure with the following protocol: the initial 5 cycles were performed with $1 \mathrm{~min}$ at $94{ }^{\circ} \mathrm{C}, 1.5 \mathrm{~min}$ at $42{ }^{\circ} \mathrm{C}$ and $1.5 \mathrm{~min}$ at $72{ }^{\circ} \mathrm{C}$, and they were followed by 35 cycles with $1 \mathrm{~min}$ at $94{ }^{\circ} \mathrm{C}, 1.5 \mathrm{~min}$ at $50^{\circ} \mathrm{C}$ and 1 min at $72{ }^{\circ} \mathrm{C}$. The amplified products were gel purified using the Wizard Gel and PCR cleaning (Promega) kit, and both strands were sequenced using a CEQ8000 Beckman Coulter sequencer. Sequences were aligned with the Clustal algorithm implemented in MEGA version 4 (Tamura et al. 2007) and checked by visual inspection. Absolute numbers of nucleotide substitutions between haplotypes were determined using PAUP* 4.01b10 (Swofford 2003). Obtained sequences were submitted to NCBI Blast and resulted to be pertaining to tardigrades (max score: 569-529; max identity: $78-81 \%$ ). The data are reported in GenBank and in the Barcode of Life Data Systems (BOLD, http://www.barcodinglife.org/views/login.php) (accession numbers: FJ184601-4)

\section{RESULTS}

\subsection{Thermal tolerance}

Survival of $B$. zetlandicus was inversely related to stress temperature (Fig. 2), showing a progressively significant decrease of viability with an increase in temperature $(\mathrm{P}<0.001$ Pearson's correlation test). Survival was $100 \%$ at $25{ }^{\circ} \mathrm{C}, 26^{\circ} \mathrm{C}$ and $28^{\circ} \mathrm{C}$, while the lethal thermal maximum $\left(\mathrm{LT}_{\max }\right)$ was $37^{\circ} \mathrm{C}$. The lethal temperature $\left(\mathrm{LT}_{50}\right)$ was $33.0 \pm 0.5{ }^{\circ} \mathrm{C}$. For control specimens maintained at $10{ }^{\circ} \mathrm{C}$, survival was $100 \%$. Percentage of animal viability significantly increased from $\mathrm{t}_{0}$ to $\mathrm{t}_{24}$ for temperatures from $26{ }^{\circ} \mathrm{C}$ to $33^{\circ} \mathrm{C}$ (Fig. 2; Mann Whitney test). Calculations of differences between the percentage of animal viability recorded at $t_{24}$ and $t_{0}$ were found to have a positive relationship with temperature $(P=0.007 ;$ Pearson's test $)$.

\subsection{Freezing tolerance}

The survival of B. zetlandicus was directly related to the cooling rate: the higher the cooling rate, the lower the survival $(P<0.001$; Pearson). The highest survival was recorded at a cooling rate of $-0.37{ }^{\circ} \mathrm{C} \mathrm{min}^{-1}(72.5 \%$, $s d=20.5)$; the lowest at $-1.95^{\circ} \mathrm{C} \min ^{-1}(12.3 \%, s d=$ $3.5 \%$ ) (Fig. 3). Significant statistical differences in survival among cooling rates were found between $-0.37^{\circ} \mathrm{C}$ $\min ^{-1}$ and $-1.95{ }^{\circ} \mathrm{C} \min ^{-1}(P<0.05)$ and between -0.69 


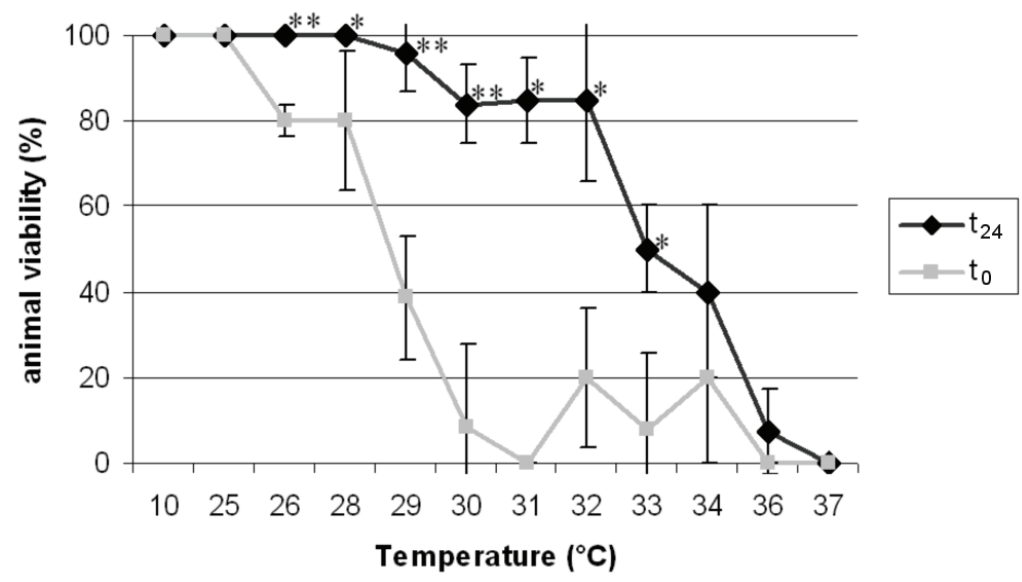

Fig. 2. Viability of Borealibius zetlandicus specimens under thermal stress. Each bar gives the mean percentage and its standard deviation. $\mathrm{t}_{0}=$ viability immediately after the end of heat stress; $\mathrm{t}_{24}=$ viability 24 hours after the end of stress (survival). Asterisks $=$ significant increase of animal viability recorded between $\mathrm{t}_{0}$ and $\mathrm{t}_{24} * 0.05<P>0.007 ; * * P \leq 0.007$.

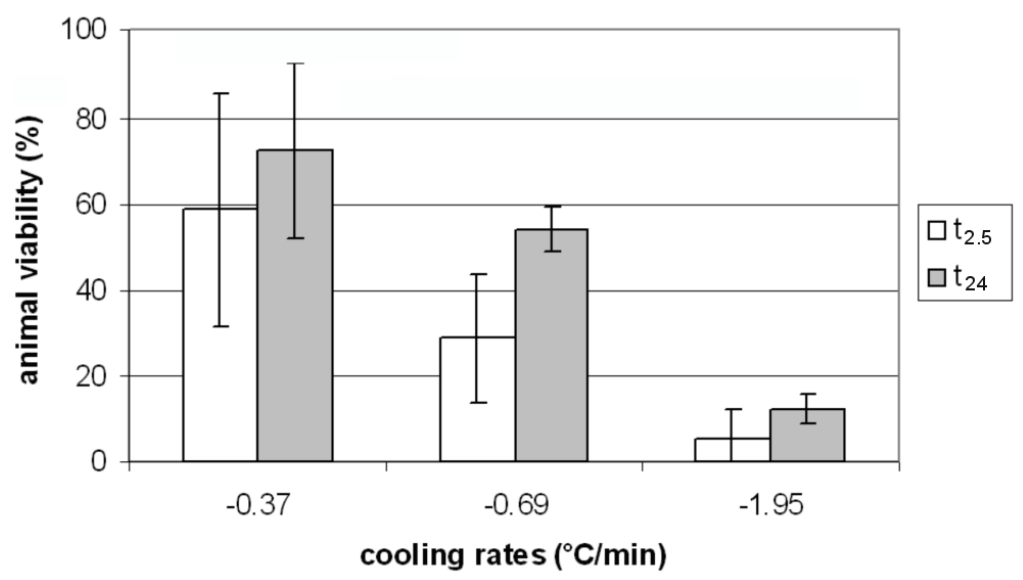

Fig. 3. Viability of Borealibius zetlandicus specimens frozen at three different cooling rates. Each bar gives the mean percentage and its standard deviation. White column $=$ viability at $\mathrm{t}_{2.5}$; gray column $=$ survival at $\mathrm{t}_{24}$.

${ }^{\circ} \mathrm{C} \min ^{-1}$ and $-1.95{ }^{\circ} \mathrm{C} \min ^{-1}(P=0.017)$. A negative correlation was found between survival and cooling rates $(P<0.001$; Pearson). The percentage of animal viability did not statistically increase from $\mathrm{t}_{2.5}$ to $\mathrm{t}_{24}$.

\subsection{Desiccation tolerance}

No specimens of $B$. zetlandicus survived desiccation.

\subsection{Molecular characterization}

Partial COI sequences of 4 specimens, representative of two populations of B. zetlandicus, were obtained and deposited in GenBank and BOLD. Unambiguous alignment of these sequences contained no gaps and was 630 bp long. A single haplotype was identified.

\section{DISCUSSION}

Several studies on the cryobiotic ability of tardigrades have dealt with species from the Arctic and Antarctic regions, where substrates are frozen for the most part of the year (Dougherty et al. 1960; Aoki \& Konno 1961; Kristensen \& Hallas 1980; Kristensen 1982; McInnes \& Ellis-Evans 1987, 1990; Grøngaard et al. 1990; Sugawara et al. 1990; Suren 1990; Grøngaard 1995; Solhenius et al. 1995; Sømme \& Meier 1995; Dastych et al. 2003). Nonetheless only a few studies have examined the tardigrade's ability to withstand extended periods at low temperatures (Sugawara et al. 1990; Sømme \& Meier 1995; Newsham et al. 2006). No data are available on the cryobiotic ability of tardigrades collected either in temperate areas or in alpine zones. The ability of the active animals of $B$. zetlandicus to freeze and survive after thawing confirms the cryobiotic ability of this species. Our results show a negative correlation between survival and cooling rates. The higher the cooling rates, the lower the survival. Other studies have shown the negative effect of increasing cooling rate on tardigrade survival (Rahm 1923; Ramløv \& Westh 1992; Sugawara et al. 1990). A negative relationship between survival and cooling rate has also been found in nematodes (Wharton et al. 2002, 2003). 
Borealibius zetlandicus has been found only in boreo-alpine areas, usually in an aquatic freshwater environment (sediment, submerged moss and sphagnum), but also in the Barents Sea, and sometimes in terrestrial substrates that rarely dry out completely (e.g., moss on soil, soil, Cyanobacteria colonies; see Pilato et al. 2006). Therefore, the ability to withstand freezing but not drying can be explained in adaptive terms. Selective pressure related to the hydrophilic environments and cold climate in which this species (or its stem group) has evolved may have led either to reducing its anhydrobiotic ability, or to preventing the evolution of this form of quiescence. It is also worthy to note that also Dactylobiotus parthenogeneticus, a true limnic species, does not carry out anhydrobiosis (Bertolani et al. 2004).

With regard to thermal tolerance, the studied population of $B$. zetlandicus shows a high capacity to resist heat-shock $\left(\mathrm{LT}_{50}=33.0 \pm 0.5{ }^{\circ} \mathrm{C}\right)$ for short periods of time (even though it lives in mosses flooded by glacial waters and then subjected to a low temperature of about $4{ }^{\circ} \mathrm{C}$ ). This ability to resist heat shock in active specimens unable to carry out anhydrobiosis leads us to think there is no direct relationship between anhydrobiosis and thermal tolerance. The ability of organisms to acquire tolerance to temperature increases represents an important adaptive strategy. Several authors have stated that this ability is bound to the habitat, to the geographic distribution, and to the daily and seasonal temperature variations, but also to the hydration state of the organism (Pough 1974; Claussen 1977; Floyd 1985; Pashkova 1985; Spotila et al. 1989; Pörtner 2002; Sørensen et al. 2005). Nevertheless, daily or seasonal temperature variation acting on the population we studied is too low to explain its thermal tolerance. Exposure of specimens of another eutardigrade species, Macrobiotus harmsworthi Murray, 1907, to an artificial thermal gradient resulted in a $\mathrm{LT}_{\max }$ of $38^{\circ} \mathrm{C}(\mathrm{Li} \&$ Wang 2005a). Macrobiotus harmsworthi is an eurytopic species with a wide distribution, it is found in several environments and substrates (among them leaf litter and mosses on rocks subject to drying), and it is considered a eurythermal species ( $\mathrm{Li} \&$ Wang 2005a) with anhydrobiotic and cryobiotic abilities (Sugawara et al. 1990; personal observations). Therefore, it is surprising to find that $M$. harmsworthi has a very similar $\mathrm{LT}_{\max }$ to $B$. zetlandicus $\left(37^{\circ} \mathrm{C}\right)$, which is a hygrophilous and, as predicted by its distribution, a stenothermal species (Pilato et al. 2006).

Even though the specimens of $B$. zetlandicus are able to withstand temperatures between $25{ }^{\circ} \mathrm{C}-33{ }^{\circ} \mathrm{C}$, some kinds of "damage" does occur during the heating. This is indicated by the increased number of animals that needed more time to recover active life after heat stress. This increase is in direct relationship to temperatures. The higher the heat stress, the higher is the number of animals affected by this "damage", whose nature remains unknown. According to the oxygen limitation hypothesis in complex metazoans, critical temperatures (low or high temperatures) affecting fitness are generally not set by cellular level responses (such as loss or modifications in lipid saturation, kinetic properties of metabolic enzymes, contractile proteins and transmembrane transporters), but are rather set by an oxygen deficiency and a transition to unsustainable anaerobic metabolism (Pörtner 2002). The ability of $B$. zetlandicus to survive relatively high temperatures can be explained by its high physiological flexibility or by its ability to withstand anoxic conditions. In agreement with the latter hypothesis, low oxygen tension values have been recorded in spring water at the sampling site. Anoxybiosis induced by reduced oxygen tension is a well-known dormancy state in tardigrades, but to date no specific studies have been carried out on this phenomenon.

In spite of its absent or reduced anhydrobiotic performance with respect to other terrestrial tardigrade species, B. zetlandicus is able to live in freshwater and wet terrestrial habitats (also marine), and it has a wide distribution in the boreal hemisphere related to cold climates. It lives at low temperatures, but it is also able to withstand temperatures above $30^{\circ} \mathrm{C}$, although only for a short time. Therefore, its wide distribution could be related to a wide tolerance to different environmental parameters, such as osmotic and temperature variations.

Very recently cryptic species have been discovered within two eutardigrade morphospecies (Rebecchi et al. 2003; Faurby et al. 2008). Borealibius zetlandicus is widespread at high latitudes and high altitudes including the boreal hemisphere and has a disjointed distribution. Therefore, we thought it important to characterize the population used in the experiments from a molecular point of view, considering the possibility that cryptic species may exist. We have investigated a tract of mtDNA belonging to the COI gene, which forms the primary barcode sequence for members of the animal kingdom (Hebert et al. 2003a, b; Savolainen et al. 2005). For comparison, another Italian population of $B$. zetlandicus (collected not far from the first one) has been characterized in the same way, with identical results (the same haplotype has been identified). The importance of this characterization is that, in general, different cryptic species can have different ecological niche and these species can easily give a different experimental response. We underline the importance of barcoding material used in the experiments as much as possible, especially when the specimens are collected in nature and are not reared in the laboratory.

\section{ACKNOWLEDGMENTS}

The authors thank Dr. Diane Nelson, East Tennessee State University, U.S.A., for the English revision of the manuscript and Prof. Michele Aleffi, University of Camerino, Italy, for identification of the mosses. We are 
also grateful to reviewers for their constructive suggestions. The research was supported by University of Modena and Reggio Emilia (50\% FAR) and by Fondazione Caritro, Rovereto (TN) (project "Ambienti estremi: cambiamenti climatici e strategie adattative in invertebrati acquatici di alta quota", 2006-2008).

\section{REFERENCES}

Aoki, K. \& H. Konno. 1961. Frost-resistance of the rotifer in Antarctic region. Bull. Mar. Biol. Stn. Asamushi, 10: 247250.

Bertolani, R., R. Guidetti, K.I. Jönsson, T. Altiero, D. Boschini \& L. Rebecchi. 2004. Experiences on dormancy in tardigrades. J. Limnol., 63: 16-25.

Claussen, D.L. 1977. Thermal acclimation in ambystomatid salamanders. Comp. Biochem. Physiol., 58A: 333-340.

Dastych, H., H. Kraus \& K. Thaler. 2003. Re-description and notes on the biology of the glacier tardigrade Hypsibius klebelsbergi Mihelčič, 1959 (Tardigrada), based on material from the Ötztal Alps, Austria. Mitt. Zool. Mus. Inst., 100: 73-100.

Degma, P. \& R. Guidetti. 2007. Notes to the current checklist of Tardigrada. Zootaxa, 1579: 41-53.

Dougherty, E.C., B.G. Chitwood \& A.R. Maggenti 1960. Observation on Antarctic freshwater micrometazoa. Anat. Rec., 137: 350.

Faurby, S., K.I. Jönsson, L. Rebecchi \& P. Funch. 2008. Variation in anhydrobiotic survival of two eutardigrade morphospecies: a story of cryptic species and their dispersal. J. Zool., 275: 139-145.

Floyd, R.B. 1985. Effects of photoperiod and starvation on the temperature tolerance of larvae of the giant toad, Bufo marinus. Copeia, 1985: 625-631.

Folmer, O., M. Black, W. Hoen, R. Lutz \& R.Vrijenhoek. 1994. DNA primers for amplification of mitochondrial cytochrome c oxidase subunit I from diverse metazoan invertebrates. Mol. Mar. Biol. Biotech., 3: 294-299.

Guidetti, R. \& R. Bertolani. 2005. Tardigrade taxonomy: an updated check list of the taxa and a list of characters used in their identification. Zootaxa, 845: 1-46.

Hand, S.C. 1991. Metabolic dormancy in aquatic invertebrates. Adv. Comp. Environm. Physiol., 8: 1-50.

Hebert, P.D.N., A. Cywinska, S.L. Ball \& J.R. deWaard. 2003a. Biological identifications through DNA barcodes. Proc. R. Soc. London B, 270: 313-321.

Hebert, P.D.N., S. Ratnasingham \& J.R. deWaard. 2003b. Barcoding animal life: cytochrome c oxidase subunit 1 divergences among closely related species. Proc. R. Soc. London B, 270: 596-599.

Grøngaard, A. 1995. The invertebrate fauna on and in the Inland Ice of Greenland. Copenhagen. Prize Essay, University of Copenhagen.

Grøngaard, A., N.M. Kristensen \& M.K. Petersen. 1990. Tardigradfaunaen på Disko. In: O.F. Andersen, L. Düwel \& O.S. Hansen (Eds.), Felkurs i Arktisk biologi, Godhavn 1990. Copenhagen: Zoological Museum, University of Copenhagen, 155-179.

Irons, J.G.III, L.K. Miller \& M.K. Oswood. 1993. Ecological adaptations of aquatic macroinvertebrates to overwintering in interior Alaska (U.S.A.) subarctic streams. Can. J. Zool., 71: 98-108.

Keilin, D. 1959. The problem of anabiosis or latent life: history and current concepts. Proc. Roy. Soc., 150B: 149-191.

Kristensen, R.M. 1982. The first record of cyclomorphosis in Tardigrada based on a new genus and species from Arctic meiobenthos. Z. Zool. Syst. Evol.forsch., 20: 249-270.

Kristensen, R.M. \& T.E. Hallas. 1980. The tidal genus Echiniscoides and its variability, with erection of Echiniscoididae, fam. nov. (Tardigrada). Zool. Scripta, 9: 113-127.
Jönsson, K.I. \& L. Rebecchi. 2002. Experimentally induced anhydrobiosis in the tardigrade Richtersius coronifer: phenotypic factors affecting survival. J. Exp. Zool., 293: 578584.

Li, X. \& Wang L. 2005a. Effect of thermal acclimation on preferred temperature, avoidance temperature and lethal thermal maximum of Macrobiotus harmsworthi Murray (Tardigrada, Macrobiotidae). J. Therm. Biol., 30: 443-448.

Li, X. \& Wang L. 2005b. Effect of temperature and thermal acclimation on locomotion performance of Macrobiotus harmsworthi Murrray (Tardigrada, Macrobiotidae). J. Therm. Biol., 30: 588-594.

McInnes, S.J. \& J.C. Ellis-Evans. 1987. Tardigrades from maritime Antarctic freshwater lakes. In: R. Bertolani (Ed.), Biology of Tardigrades. Selected Symposia and Monographs, U.Z.I. 1. Mucchi Editore, Modena: 111-123.

McInnes, S.J. J.C. Ellis-Evans. 1990. Micro-invertebrate community structure within a maritime Antarctic lake. Proc. NIPR Symp. Polar Biol., 3: 179-189.

Mora, C. \& M.F. Maya. 2006. Effect of the rate of temperature increase of the dynamic method on the heat tolerance of fishes. J. Therm. Biol., 31: 337-341.

Nelson, D.R. \& N.J. Marley. 2000. The biology and ecology of lotic Tardigrada. Freshwat. Biol., 44: 93-108.

Newsham, K.K., N.R. Maslen, S.J. McInnes. 2006. Survival of Antarctic soil metazoans at $-80{ }^{\circ} \mathrm{C}$ for six years. Cryoletters, 27: 269-280.

Pashkova, I.M. 1985. Seasonal changes in the heat resistance of Bufo viridis and its muscles and of the contractile muscle models. J. Therm. Biol., 10: 105-108.

Pilato, G., R. Guidetti, L. Rebecchi, O. Lisi, J.G. Hansen \& R. Bertolani. 2006. Geonemy, ecology, reproductive biology and morphology of the tardigrade Hypsibius zetlandicus (Eutardigrada: Hypsibiidae) with erection of Borealibius gen. n. Polar Biol., 29: 595-603.

Pough, F.H. 1974. Natural daily temperature acclimation of eastern red efts, Notophthalmus v. viridescens (Rafinesque) (Amphibia: Caudata). Comp. Biochem. Physiol., 47A: 71-78

Pörtner, H.O. 2002. Climate variations and the physiological basis of temperature dependent biogeography: systemic to molecular hierarchy of thermal tolerance in animals. Comp. Biochem. Physiol., 132A: 739-761.

Rahm, P.G. 1923. Biologische und Physiologische Beiträge zur Kenntnis der Moosfauna. Z. Allg. Physiol., 20: 1-34.

Ramløv, H. \& P. Westh. 1992. Survival of the cryptobiotic eutardigrade Adorybiotus coronifer during cooling to $-196^{\circ} \mathrm{C}$ : effect to cooling rate, trehalose level, and shortterm acclimation. Cryobiology, 29: 125-130.

Rebecchi, L, T. Altiero \& R. Guidetti. 2007. Anhydrobiosis: the extreme limit of desiccation tolerance. Invertebr. Surv. $J ., 4: 65-81$.

Rebecchi, L., V. Rossi, T. Altiero, R. Bertolani \& P. Menozzi. 2003. Reproductive modes and genetic polymorphism in different populations of the tardigrade Richtersius coronifer (Eutardigrada, Macrobiotidae). Invertebr. Biol., 122: 19-27.

Savolainen, V., R.S. Cowan, A.P. Vogler, G.K. Roderick, R. Lane. 2005. Towards writing the encyclopaedia of life: an introduction to DNA barcoding. Phil. Trans. R. Soc. London B, 360, 1805-1811.

Sohlenius, B., S. Boström \& A. Hirschfelder. 1995. Nematodes, rotifers and tardigrades from nunataks in Dronning Maud Land, East Antarctica. Polar Biol., 15: 51-56.

Sømme, L. 1996. Anhydrobiosis and cold tolerance in tardigrades. Eur. J. Entomol., 93: 349-357.

Sømme, L. \& T. Meier. 1995. Cold tolerance in Tardigrada from Dronning Maud Land, Antarctica. Polar Biol., 15: 221-224.

Sørensen, J.G., F.M. Norry, A.C. Scannapieco \& V. Loeschcke. 2005. Altitudinal variation to stress resistance traits and 
thermal adaptation in adult Drosophila buzzatii from the New World. J. Evol. Biol., 18: 829-837.

Spotila, J.R., E.A. Standora, D.P. Easton \& P.S. Rutledge. 1989. Bioenergetics, behavior, and resource partitioning in stressed habitats: biophysical and molecular approaches. Physiol. Zool., 62: 253-285.

Sugawara, H., K. Tanno, Y. Ohyama \& H. Fukuda. 1990. Freezing-tolerance of Macrobiotus harmsworthi (Tardigrada) and Plectus antarcticus (Nematoda) in the Antarctic Region. Antarctic Rec., 34: 292-302.

Sunnucks, P. \& D.F. Hales. 1996. Numerous transposed sequences of mitochondrial cytochrome oxidase I-II in aphids of the genus Sitobion (Hemiptera: Aphididae). Mol. Biol. Evol., 13: 510-523.

Suren, A. 1990. Microfauna associated with algal mats in melt pond of the Ross Ice Shelf. Polar Biol., 10: 329-336.

Received: September 2008

Accepted: November 2008
Swofford, D.L. 2003. PAUP - Phylogenetic Analysis Using Parsimony. Ver. 4.0 [Computer software and manual]. Sunderland: Sinauer Associates, Massachusetts, USA.

Tamura, K., J. Dudley, M. Nei \& S. Kumar. 2007. MEGA4: Molecular Evolutionary Genetics Analysis (MEGA), software version 4.0. Mol. Biol. Evol., 24: 1596-1599.

Wharton, D.A., G. Goodal. \& C.J. Marshall. 2002. Freezing rate affects the survival of a short-term freezing stress in Panagrolaimus davidi, an Antarctic nematode that survives intracellular freezing. Cryoletters, 23: 5-10.

Wharton, D.A., G. Goodal \& C.J. Marshall. 2003. Freezing survival and cryoprotective dehydration as cold tolerance mechanisms in the Antarctic nematode Panagrolaimus davidi. J. Exp. Biol., 206: 215-221.

Willmer, P., G. Stone \& I. Johnston. 2000. Environmental Physiology of Animals. Blackwell Science Ltd, Oxford, UK: $644 \mathrm{pp}$. 